\title{
Student Centric Pragmatic Approach to Impart Concepts of Python Applications Programming
}

\author{
Geetha Kiran Annegowda ${ }^{1}$, Mohana Lakshmi $\mathbf{J}^{2}$ \\ ${ }^{1}$ Department of Computer Science and Engineering, Malnad College of Engineering, Hassan, Karnataka, India \\ ${ }^{2}$ Department of Electrical and Electronics Engineering, Malnad College of Engineering, Hassan, Karnataka, India \\ geethaamk@gmail.com \\ 2mohana2024@gmail.com
}

\begin{abstract}
Project Based Learning (PBL) typically needs critical thinking, problem solving capability, collaboration, and different forms of communication. To cope-up with the technological standards and create superior work, it is essential for students to do significantly more than memorising the shared information. They need to use superior intellectual skills and learn to work in team. To ensure our students are engaging in quality Project Based Learning, department of Computer Science and Engineering, Malnad College of Engineering has attempted a framework to learn a programming course in a deeper way by exploring local problems and challenges. Python programming typically being a programming language needed an alternative teaching methodology to impart students the necessary technical skills and problem-solving capability. Hence, a systematic approach motivating the students to understand the syntax and apply the same to provide simple solutions to local problems was adopted. The approach started by assigning certain topics of the course to the students. These topics were presented to their peers at the end of second month of the semester. This improved active learning by the students. The syntax and contents facilitated by the students helped them to come out with excellent solutions to local problems in
\end{abstract}

\section{Geetha Kiran Annegowda}

Department of Computer Science and Engineering, Malnad College of Engineering, Hassan, Karnataka, India geethaamk@gmail.com the form of projects. The process focussed much on improving critical thinking, problem solving, communication, team work and better understanding of the concepts among the students. The approach resulted in improved learning abilities of the students and exhibited effective collaborative learning skills. Also, the projects developed provided solutions to the local problems of the society. The success rate of implementation of student-centred approach to impart programming concepts, paved way for following the same approach to teach other programming languages.

Keywords: Python Programming, Local Problems, Hands-on Sessions

\section{Introduction}

Project Based Learning (PBL) is engrained in the enlightened way being encouraged to be student centric and pragmatic method to learn subject in depth by exploring problems faced in day-to-day life. Project-Based Learning has proved to improve student retention, increase enduring interest, and improve performance in design courses. PBL can take a number of forms. Typically, while teaching a programming language, students have to be given detailed instructions to come out with better understanding and problem-solving capability. Significant objective of PBL activity is to develop efficient technical skills for students'. The purpose of such projects mainly lies in developing students' 
understanding in the procedures of scientific investigation and awareness of the nature and practices of scientific research within their particular discipline. This will be done through a process of enculturation [1]. The programming concepts delivered is intended to take a form of mini project. This process allows the students to work and think as scientists. In practice, within the timescale of an undergraduate programme, it is a challenging task since lot of students find this transition from conventional process of learning to open ended project-based learning hard. The students require preparation and support if they are to make the most of the experience. The theoretical knowledge acquired by the students is limited when executing a project. The students find it difficult to collect the necessary data and are unaware of what is to be achieved. Many students have limited awareness of the connection between theory and data. They are unaware that results can be interpreted from theory and vice-versa. Consequently, they find it difficult to interpret the results which they get. These difficulties have led students to feel demoralised [2]. To overcome these difficulties, a pragmatic approach is implemented and mini-projects are included in third year course Python Programming as activity [12].

In [3], the author's opinion that learning programming is not an easy task. This requires good understanding of theories and syntax of the programming languages. The study recommended important strategies that can be adopted to overcome the challenges in teaching programming. The five key strategies imposed are unplugged, contextualized tasks, combined learning, computational thinking and programming tasks. All these strategies are based on active learning approaches. Adopting these strategies be can find improvement in student involvement to enhance their knowledge and understanding of the course of study.

In this context the authors of this paper have proposed a response to one of the mostly asked question: "How to improve teaching programming using active learning approaches?" In response, faculty evolved on offering and conducting a course on Python Programming using active learning viz.., "Problem- Based Learning".

It was in the early 1960's PBL was first adapted in medical sciences. Today, PBL is gaining utmost importance and is effectively practised by many higher education institutions in imparting active learning. More recently it is adopted in engineering education to impart effective computing skills. A systematically mapped approach using PBL from 1997 to 2011 to teach computing is addressed. [4]. Also, sources such as IEEE, Scopus, Science Direct etc., were analysed.

The definition of PBL is well addressed as a student centric methodology. Here more than one problem is addressed. This enables students to adapt efficient technical skills in order to solve the local problems, through teamwork and collaboration [5]. Over the last few years, PBL has been adapted in teaching software programming, and has seen successful results especially in computer education [6], [7], and [8].

PBL approach has brought out a reflective educational transformation and a new culture in teaching-learning process. It is considered as one of the most innovative teaching techniques in most of the educational institutions. The choice of the course Python is justified as it is prominently used in renowned applications like Google, Instagram and YouTube [9], [10].

Python being an easy programming language has found its applications in various fields of engineering and technology. Imparting programming skills to students required a different course delivery strategy. Also, performance of students in logically analysing and applying the programming skills was quite low. Students were able to execute programs given and practised in class, whereas, they found it difficult to apply programming knowledge to solve any realistic projects. Students lacked the skills in identifying local problems and apply programming knowledge to solve the same. Also, it was observed that students had no experience in effective collaborative learning. To overcome, these gaps identified in student learning, the structure of the course design and delivery were suitably modified. To enhance the learning abilities and impart knowledge to apply python programming concepts to solve societal problems, project-based learning was implemented as an activity in the course.

This paper reports on study of adapting mini projects within a third year undergraduate Python programming course with a limited scope. The projects intend to teach students the process of designing and conducting open-ended investigations. The expectation is that students, through their experience of these mini-projects, will become more aware of the aforesaid issues identified and as a result develop more realistic expectations for open ended 
project work. This process also helps the students to develop an ability to work both as an individual and also in a team.

This study investigated:

- The extent to which the objectives and outcomes of the course were met, from the teacher's perspective and from the students' perspective

- The factors which helped or hindered the achievement of these objectives and outcomes.

This paper describes an intrusion to boost students' learning by involving students in brainstorming activities about sustainability ideas and their impact in Python Programming.

\section{Project Based Learning approach}

To begin with, data regarding course documentation, observation of the introductory sessions and group presentations, observation of one group of students throughout their project, analysis of students at different stages of their work on the miniprojects were framed. Today, technological advancements require a developer with efficient programming skills in Python. Python has found its place where it is significantly used to build websites, create learning algorithms, and perform various other tasks. Trying to learn Python may be quite frustration and difficult, especially if the approach to learn the language is not known. The approach discussed here suggests the use of PBL with respect to five major elements: Problems, Ideas, Knowledge, Learning issues and Course of action as depicted in Fig. 1.

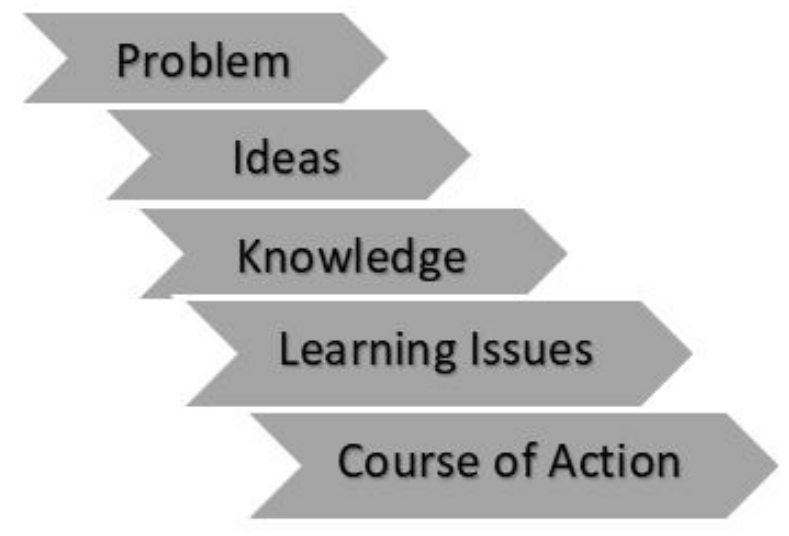

Fig. 1: Project Based Learning Approach indicating the five key elements.
This section elucidates the process of planning the activity, executing, evaluating and further identifying the strengths and improvements in the student learning process adopted in the programming courses offered in the department of Computer Science and Engineering.

\section{A. PLAN}

The aim of the teaching-learning process was, dissemination of programming knowledge and introduce potential IT students to practice. The lecture hours include 16 weeks, lasting three hours/week, totalling 40 hours with extra hours allocated to carry out the activity

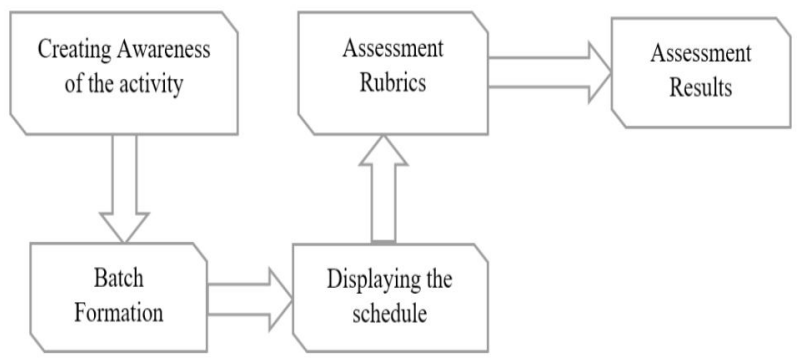

Fig. 2: Planning Approach of the Course Python Programming.

1. Creating awareness about the activity: Students were initially informed the need and outcomes of the learning approach. The ultimate goal of the course project is to provide students a platform where they can apply Python programming concepts learned in the classroom.

2. Forming student Batches: Students were grouped into a batch of 7-8 as per their comfort. Care was taken that there were students of all levels in every batch. Every student had to collaborate with each other to develop a feasible solution sharing their knowledge.

3. Schedule display: Schedule of the activity was announced which included the tasks to be completed over the next few days. Certain topics of the course was allotted to the students to educate their peers. This accelerated team collaboration, inculcate beliefs on their peers and enhanced teamwork. The course activity was planned well in advance and designed such that it provides every team an opportunity to experiment with the information obtained from the course and come out with a mini project. 
4. Assessment method: The progress of the work was monitored in regular interval. The course faculty provided a correlation of theory with practice during that time.

5. Tools and Measures: Rubrics for project assessment were developed. This focused on improvising the attainment of graduate attributes $(3,5,6,9 \& 10)$.

6. Results: Results after assessment were used to provide feedback, which motivated the students to identify the positive features and address areas of concern of the course activity. Few of the topics ended up with hardware projects with the support of faculty from Electrical and Electronics Engineering department [13].

\section{B. Research Methodology}

As the course delivery was planned to include mini project with presentations, formation of private student groups was followed. The students had the freedom to select their team with whom they feel comfortable to work with. As the group had more of like-minded students, fast learning was observed in few groups. They could work and collaborate effectively.

Few groups had only slow learners and few had highly competent students. In such cases, the group strength and weakness were studied and regrouping was done for few batches.

The total strength of the class accounted 70 students, with 31 boys and 39 girl students. Each group composed of 7-8 students and around 8 project batches were formed.

Project sectors were identified. These included, health, agriculture, security, education etc. Certain topics of the course was allotted to the students to

Table 1: Sample Questionnaire.

\begin{tabular}{|l|l|}
\hline 1 & $\begin{array}{l}\text { Identify and select relevant sectors such as } \\
\text { health, agriculture, education, security etc. }\end{array}$ \\
\hline 2 & $\begin{array}{l}\text { Identify relevant local problems in the vicinity } \\
\text { with respect to the sector selected. }\end{array}$ \\
\hline 3 & $\begin{array}{l}\text { Analyse the problem and apply knowledge } \\
\text { gained through the concepts. }\end{array}$ \\
\hline 4 & $\begin{array}{l}\text { Design a feasible solution for the problem } \\
\text { identified. }\end{array}$ \\
\hline 5 & Use modern tools/platform to execute the work. \\
\hline 6 & Test and finalize the results. \\
\hline
\end{tabular}

educate their peers where and when required. A sample questionnaire as shown in Table 1 was used for the execution of the activity.

Weekend seminars were conducted, where the students discussed the topics allotted to them with their peers. These concepts were utilized to work with the project.

As python is with lot of built-in functions, it was easy for the students to utilize their time in coding and implementing the project. Students used Anaconda, a free open source platform for carrying out their projects [14].

List of projects selected and executed by students is as given in Table 2.

Table 2 : Project List.

\begin{tabular}{|l|l|}
\hline 1 & Security maintenance using Raspberry pi \\
\hline 2 & $\begin{array}{l}\text { Temperature monitoring device using Bolt IoT } \\
\text { Module }\end{array}$ \\
\hline 3 & Face recognition with OpenCV \\
\hline 4 & Stock market prediction \\
\hline 5 & Creating website using flask framework \\
\hline 6 & $\begin{array}{l}\text { Building a chat box using machine learning in } \\
\text { python }\end{array}$ \\
\hline 7 & Attendance manager \\
\hline 8 & $\begin{array}{l}\text { Hand gesture mouse control using OpenCV and } \\
\text { python. }\end{array}$ \\
\hline
\end{tabular}

The details of complete execution and assessment methods followed is discussed in the sections to follow.

\section{Execution}

Being assigned the course on python programming for the 3rd year students, I wanted to make it interesting by activities rather than monotonous way of teaching. I motivated and educated the students that programming language can be learnt best through projects.

Student activity and Class room lectures went on together with hands on sessions. A whole month was given for preparation of the seminar topic which made them understand the complete syllabus by the end of second month. Each student had an opportunity to discuss contents of the course allotted to them with their peers. Later, concepts learnt were well utilised to solve the identified local problems. Fig. 3 shows the snapshot involved in delivering the course contents and peer learning $[11,16,17]$. 


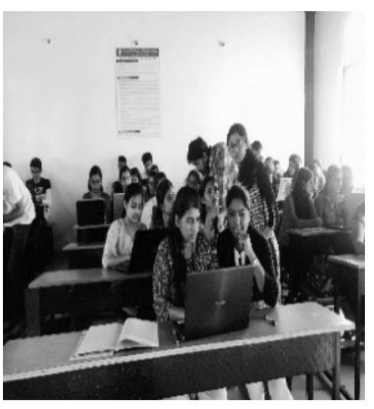

Fig. 3 (a)

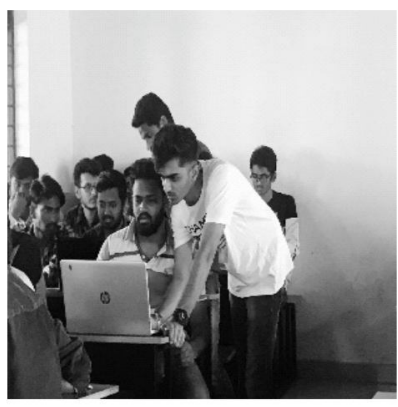

Fig. 3 (b)
Fig. 3: Snapshots indicating student seminar and peer learning.

Also, through this the approach I wanted the students to learn tools [15] for interfacing with external hardware, for example using Arduino, sensors, and wireless networks. This would lead the students to apply coding and improve the quality of projects. Through this, I wanted the students to understand the depth of learning a programming language while trying to solve the problem assigned to them. This approach intended to give the students an opportunity to manage the projects and internal evaluations without compromising their performance. Also, the activity is an effort to bring innovations in teaching learning process where students were made to execute program after each topic discussion.

Based on their experiences and challenges in the society, students identified problems. Every group had the support of the course faculty. The students were structured into teams of 7-8 members. Content support of the course Python Programming was provided to students in the ppt. format. Teaching and project execution were carried out in parallel.

Initially, the students started developing the required code and further went with the implementation of the hardware circuitry. The entire process was kept track and the progress of each team was monitored regularly. The entire process was assessed through student feedback and was also evaluated through external juries on the final project evaluation day.

\section{Assessment}

It's too early to assess the effect of the class on student learning and retention. Students' survey and final grades gave encouraging results. Assessment was carried out for calculating the attainment of the graduate attributes/program outcomes viz., PO: 3, 5, 6, 9 and 10. These attribute to Need, Conceptual, Modern Tool Usage and Team Work.
PO-3 attributes to Design \& Development of Solutions.

PO-5 points to Modern Tool usage.

PO-6 refers to Engineering \& Society.

PO-9 attributes to Individual \& Team Work

PO-10 denotes communication.

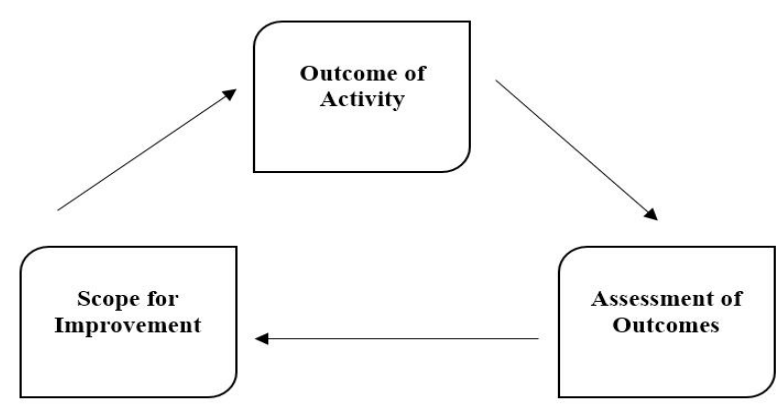

Fig.4: Assessment process.

Fig. 4 shows the assessment process followed to measure the outcome of the activity. A scope for further improvement of the activity was also carried out. The mini projects submitted were later used as a means of assessing if or not the course faculty and the students were able to meet the course objective and goals.

A general format for assessing the course activity was developed and evaluation was made on that ground. The course activity intended to impart specific skills that would help in attaining the graduate attributes. Specific criteria for assessment was developed. Table 3 summarises the criteria used for assessing the outcomes of the course project.

Table 3: Assessment Criteria.

\begin{tabular}{|l|l|}
\hline \multicolumn{2}{|c|}{ Students have to develop competence to: } \\
\hline 1 & $\begin{array}{l}\text { Use the theoretical aspects and concepts studied } \\
\text { through lectures in developing solutions to the } \\
\text { projects selected. }\end{array}$ \\
\hline 2 & $\begin{array}{l}\text { Improve self -learning ability by learning new and } \\
\text { advanced technologies }\end{array}$ \\
\hline 3 & $\begin{array}{l}\text { Use analytica 1 approach to solve the problems } \\
\text { identified }\end{array}$ \\
\hline 4 & $\begin{array}{l}\text { Become familiar with the advancements in } \\
\text { applications of python programming }\end{array}$ \\
\hline 5 & $\begin{array}{l}\text { Troubleshoot any error that occurs in a systematic } \\
\text { process }\end{array}$ \\
\hline 6 & $\begin{array}{l}\text { Develop efficient team work and manage project } \\
\text { completion successfully }\end{array}$ \\
\hline
\end{tabular}


E. Assessment Rubrics:

Significance of rubrics lies in measuring the students' performance in executing the course project. As the course activity aimed in building engineering skills in the students a well-planned rubric that covered the essential graduate attributes was developed. Table 4 provides the rubric developed for evaluating the performance. The rubric gave the students a clear understanding on how their performance would be measured. Assessment was made both on individual and team performance. During presentation the students would be intervened to test their knowledge. Parameter $2 \& 4$ were used for assessing individual performance while parameter 1 $\& 3$ for assessing the group.

\section{Results}

Table 4: Rubrics for the course (Python Programming) activity assessment.

\begin{tabular}{|c|c|c|c|}
\hline Parameter & $\begin{array}{c}\text { Outstanding } \\
{[100 \% \text { of allocated }} \\
\text { marks }]\end{array}$ & $\begin{array}{l}\text { Good }[60 \% \\
\text { of allocated } \\
\text { marks] }\end{array}$ & $\begin{array}{c}\text { Fair }[20 \% \text { of } \\
\text { allocated } \\
\text { marks] }\end{array}$ \\
\hline $\begin{array}{l}\text { Problem } \\
\text { statement } \\
\& \\
\text { Technology } \\
{[3]}\end{array}$ & $\begin{array}{l}\text { Innovative ideas and } \\
\text { addresses local } \\
\text { problems. }\end{array}$ & $\begin{array}{l}\text { Moderately } \\
\text { addresses } \\
\text { local problem }\end{array}$ & $\begin{array}{l}\text { Concepts not } \\
\text { clear }\end{array}$ \\
\hline $\begin{array}{l}\text { Implementa } \\
\text { tion [3] }\end{array}$ & $\begin{array}{l}\text { High level design. } \\
\text { All objectives well } \\
\text { defined. } \\
\text { Implementation } \\
\text { processes clearly } \\
\text { specified. }\end{array}$ & $\begin{array}{l}\text { Methodology } \\
\text { followed is } \\
\text { specified but } \\
\text { detailing is } \\
\text { not done. }\end{array}$ & $\begin{array}{l}\text { Significant } \\
\text { amount of } \\
\text { technical } \\
\text { detail is } \\
\text { lacking or } \\
\text { inadequate }\end{array}$ \\
\hline $\begin{array}{l}\text { Outcomes } \\
{[3]}\end{array}$ & $\begin{array}{l}\text { Complete } \\
\text { explanation of key } \\
\text { concepts. Strong } \\
\text { description of the } \\
\text { technical } \\
\text { requirements. } \\
\text { Results presented in } \\
\text { very appropriate } \\
\text { manner }\end{array}$ & $\begin{array}{l}\text { Description } \\
\text { of technical } \\
\text { requirements } \\
\text { is in } \\
\text { sufficient. } \\
\text { Partial } \\
\text { justification } \\
\text { for the Tool } \\
\text { being used }\end{array}$ & $\begin{array}{l}\text { Partial } \\
\text { Explanation } \\
\text { of } \mathrm{t} \text { he ke } \mathrm{y} \\
\text { concepts and } \\
\text { in-sufficient } \\
\text { description of } \\
\text { the technical } \\
\text { requirements }\end{array}$ \\
\hline $\begin{array}{l}\text { Presentatio } \\
\text { n skills [1] }\end{array}$ & $\begin{array}{l}\text { Well organized } \\
\text { presentation }\end{array}$ & $\begin{array}{l}\text { Slides not } \\
\text { well } \\
\text { organized, } \\
\text { presentation } \\
\text { not much } \\
\text { satisfactory }\end{array}$ & $\begin{array}{l}\text { Poor } \\
\text { organization } \\
\text { and } \\
\text { presentation }\end{array}$ \\
\hline
\end{tabular}

To measure student attitude during and after the class, surveys were conducted. These surveys measured students' perception of their own success journey of carrying out the activity, their interest in the major and the resulting career, and their enthusiasm for the subject. Two surveys were done to analyse the response of the students before and after execution of the activity. Table 5 shows the response recorded.
Table 5: Responses recorded based on student feedback

\begin{tabular}{|l|l|l|}
\hline \multicolumn{1}{|c|}{ Question } & $\begin{array}{c}\text { Before the } \\
\text { activity }\end{array}$ & $\begin{array}{c}\text { After the } \\
\text { activity }\end{array}$ \\
\hline $\begin{array}{l}\text { Ability to develop a program using } \\
\text { Python }\end{array}$ & $39 \%$ & $81 \%$ \\
\hline $\begin{array}{l}\text { Ability to critically think about a } \\
\text { program }\end{array}$ & $66 \%$ & $92 \%$ \\
\hline Ability to work with others & $77 \%$ & $89 \%$ \\
\hline $\begin{array}{l}\text { Are you likely to choose your career } \\
\text { applying python programming? }\end{array}$ & $51 \%$ & $83 \%$ \\
\hline $\begin{array}{l}\text { Does the course and the activity offer } \\
\text { multidisciplinary research? }\end{array}$ & $60 \%$ & $86 \%$ \\
\hline
\end{tabular}

Table 5 summarises the response of the student to selected questions before and after the completion of the course. The results suggested that the students are largely passionate in using Python Programming as a career option.

Project based learning has led to positive developments especially on students' involvement, a motivated behaviour, and beliefs on their efficacy. Overall purpose of making students understand the concepts of a programming language through projectbased learning was satisfactory. Students exhibited a high level of enthusiasm in the learning process and developed a great responsibility in providing a solution to the assigned problems. Each of the projects were evaluated by the external juries and three best projects were awarded. This approach laid a foundation for the students of the 6th semester to carry out their final year projects. Fig. 5 shows the snapshot of execution, evaluation, demonstration by the students and evaluation by an external jury member. Three (3) best projects were selected and awarded with cash prizes to motivate them further. Head of the department appreciated the conduction and execution of the activity.

The entire process was enjoyed and kept the students excited about the happenings of the activity. Students were able to explore variety of ideas. Being the course faculty, I found that such realistic projects considerably magnified the programming skills and kept the students engaged actively throughout the activity [18]. The process focussed much on improving critical thinking, problem solving, communication, team work and better understanding of the concepts among the students [19].

Through project demos and presentation, each of the graduate attribute was evaluated. The attainment of the PO's $(3,5,6,9 \& 10)$ were documented. Table 6 provides the class attainment of program outcome. 


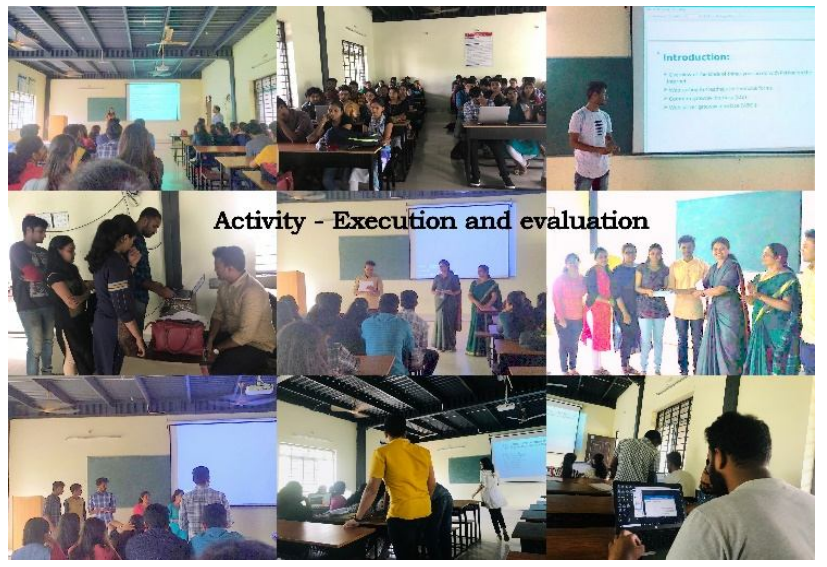

Fig. 5: Activity execution, demonstration and evaluation by external jury.

Table 6: Attainment of POs

\begin{tabular}{|c|c|}
\hline Program Outcomes & \% Attainment \\
\hline PO-3 & 72.33 \\
\hline PO-5 & 83.15 \\
\hline PO-6 & 76.53 \\
\hline PO-9 & 80.53 \\
\hline PO-10 & 78.14 \\
\hline
\end{tabular}

Through PBL approach few of the issues pertaining to attainment of POs for NBA are addressed.

The attainment of POs was calculated based on feedback from the students. A questionnaire describing each of the PO was provided and the feedback received from the students is used to arrive at the attainment value. Without willingness to learn the subject and involvement to carry out the project it is tough to get students to appreciate process of adapting PBL. The difficulties encountered by students were managed by monitoring of the concerned course faculty in some groups and even changes in the team structures which enabled them to adapt to project interests of their peers.

The students provided feedback at the end of the project. Few important outcomes were:

- The course provided a platform for the students to gain knowledge and develop requisite skills (analytical and logical) for solving the identified problem.

- It was an opportunity for the students to think outside the box
- Students were conscious about their responsibility for executing project

- Students encultured team work and also, they found a profound improvement in exhibiting their leadership qualities

Project success was typically high, with completion rates in the $95 \%$ range

The activity and the entire process was reviewed thoroughly by the students. The students were able to explore and extend variety of ideas during this process. When students were asked in surveys if this activity-based approach reinforced their programming principles, enabled them to critically think and apply the concepts effectively and efficiently to come out with a prototype, a majority agreed strongly that it did. This is as shown in Fig. 6. Effectiveness of the approach was measured on the parameters such as Collaborative learning, group processing, positive interdependence, faculty intervention, learning by doing, sharing ideas and scope for research. The feedback from the students further motivated the course faculty to look for further avenues in improving activity-based learning and putforth more effort in bringing out novelty in teachinglearning process.

There was a significant improvement in the Course Outcome attainment with the implementation of PBL in the course. Table 7 provides the $\mathrm{CO}$ attainment obtained after the semester end examination. Table 6 gives the values of $\mathrm{CO}$ attained of two consecutive batches.

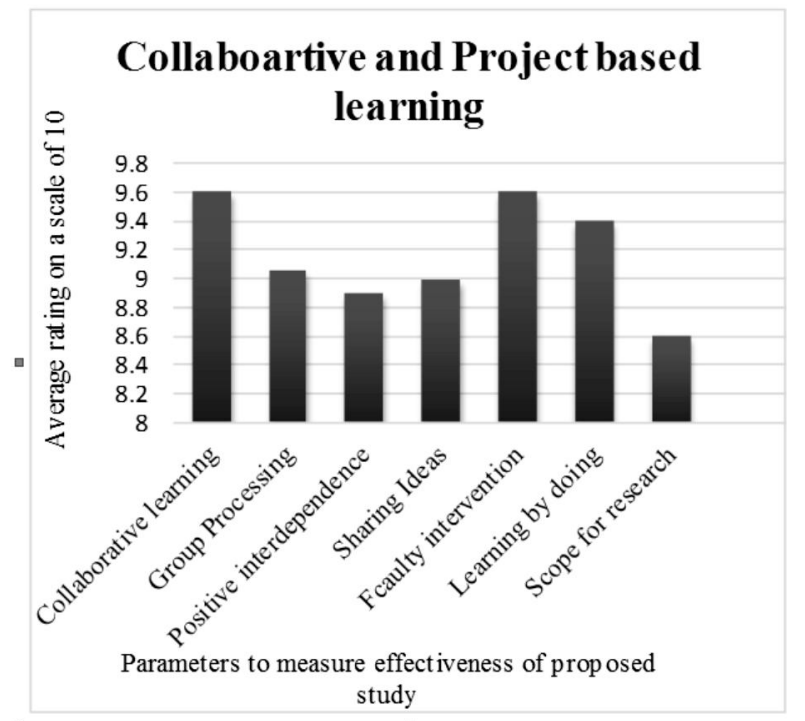

Fig.6: Result of survey depicting effectiveness of PBL. 
The activity and the entire process was reviewed thoroughly by the students. The students were able to explore and extend variety of ideas during this process. When students were asked in surveys if this activity-based approach reinforced their programming principles, enabled them to critically think and apply the concepts effectively and efficiently to come out with a prototype, a majority agreed strongly that it did. This is as shown in Fig. 6. Effectiveness of the approach was measured on the parameters such as Collaborative learning, group processing, positive interdependence, faculty intervention, learning by doing, sharing ideas and scope for research. The feedback from the students further motivated the course faculty to look for further avenues in improving activity-based learning and putforth more effort in bringing out novelty in teachinglearning process.

There was a significant improvement in the Course Outcome attainment with the implementation of PBL in the course. Table 7 provides the $\mathrm{CO}$ attainment obtained after the semester end examination. Table 6 gives the values of $\mathrm{CO}$ attained of two consecutive batches.

Table 7: Attainment of CO's

\begin{tabular}{|c|c|c|}
\hline COs & $\begin{array}{c}\text { Before the } \\
\text { activity }\end{array}$ & After the activity \\
\hline $\mathrm{CO} 1$ & 76.52 & 78.75 \\
\hline $\mathrm{CO} 2$ & 71.03 & 76.28 \\
\hline $\mathrm{CO} 3$ & 73.20 & 89.93 \\
\hline $\mathrm{CO} 4$ & 72.11 & 82.98 \\
\hline $\mathrm{CO} 5$ & 70.86 & 81.53 \\
\hline
\end{tabular}

\section{Conclusion and Future Plans}

Collaboration and life-long learning are key facts more likeable to a wider and also diverse set of students. Without any doubt, teaching programming courses requires a substantial element to a bring success to undergraduate student experience. This will further help to improve performance, and make efficient time investment. The constructivist course activity, planning and execution presented here can substantially reduce the effort required to effectively conduct such classes. PBL helped students enabling them to adopt research and investigation. It has also helped in enhancing the confidence and be updated on the topic chosen for study. Students observed a greater improvement in their communication, analytical and presentation skills. It has also shown dynamic behaviour by the teams during project designing and working in small groups. The students came across variety of societal problems identified by their peers also. Further, they showed immense interest in learning from peers. Hence, as a future course of action each team has been asked to make video recordings of their work and seminar topics and make it available in the department website so that it is accessible by all other students. Also, the success rate of implementation of student-centred approach to impart programming concepts, has been planned to be applied in all the other subjects related to programming languages and redesign the entire course structure accordingly.

\section{References}

[1] Jennifer M. Case and Gregory Light (2011), "Emerging Methodologies in Engineering Education Research", Journal of Engineering Education, Vol. 100, No.1, pp. 186-210.

[2] Patall, E. A., Cooper, H., and Robinson, J. C. (2008), "The effects of choice on intrinsic motivation and related outcomes: A metaanalysis of research findings", Psycho-logical Bulletin, Vol. 134, No. 2, pp. 270.

[3] Pellegrino, J. W., and Hilton, M. L. (2012), "Education for life and work: Developing transferable knowledge and skills in the 21st century", Washington, DC: National Academies Press.

[4] Wirkala, C., and Kuhn, D. (2011), "Problembased learning in K-12 education: Is it effective and how does it achieve its effects?", American Educational Research Journal, Vol. 48, No. 5, pp. 1157-1186.

[5] Thomas, J. W. (2000), “A review of research on project-based learning", San Rafael, CA: The Autodesk Foundation.

[6] Roy C. H., Wen-Chung Liu, (2005) "Project based learning as a pedagogical tool for embedded system education", 3rd International Conference on information technology: Research and Education.

[7] Andrei M. R., Tudor H. P, Vasile-Danut M. and Bogdan I. (2017), "Problem-based learning and Project based learning concepts and their applications to engineering education", 16th RoEduNet Conference: Networking in Education and Research. 
[8] Yakup D., Ayşegül U. (2016), "Project based learning using student clubs and short online videos, in-class activities", 15th International Conference on Information Technology Based Higher Education and Training (ITHET).

[9] Jiabin Z., Rongrong L., Qunqun L., Tianyi Z. and Zhinan Z. (2019), "Engineering Students' Epistemological Thinking in the Context of Project-Based Learning", IEEE Transactions on Education, Vol. 62, Issue 2, pp. 188-198.

[10]Vicente L. (2017), “Innovative learning in engineering education: Experimenting with short-term project-oriented research and projectbased learning", IEEE 26th International Symposium on Industrial Electronics (ISIE).

[11]Geetha Kiran A. and Uma B. (2016), "Tutoring junior Undergraduate Students by seniors in Engineering Courses", Journal of Engineering Education Transformations; Vol. 30, Issue 2.

[12]Sunitha P., Geetha Kiran A. and Uma B. (2016), "Effective Teaching through Programming Assignments", Journal of Engineering Education Transformations; Special Issue.

[13]Geetha Kiran A., Mohana Lakshmi J. and Nanditha B. R. (2018), "Inter-Departmental Student Projects- Challenges and Benefits", Journal of Engineering Education Transformations, Special Issue, eISSN 23941707.
[14]Anaconda packages, General purpose programming languages available at https://anaconda.org/anaconda/python

[15]Chandrashekar H. S., Geetha Kiran A. and Nanditha B. R. (2018), "Introducing Programming using "Scratch" and "Greenfoot", Journal of Engineering Education Transformations; Special Issue.

[16]Uma B., Geetha Kiran A., Sunitha P. and Chandrashekar H. S. (2018), "Effective Tutoring with Senior Students Assistance, Journal of Engineering Education Transformations"; Volume 31, Issue 3, pp. 109-113.

[17]Uma B., Geetha Kiran A. and Sunitha P. (2017), "A Practical Approach to Make Computer Laboratory Courses More Effective and Interesting through Student Mentoring", Journal of Engineering Education Transformations; Volume 31, Issue 1, pp. 37-41.

[18]Geetha Kiran A. and Uma B. (2017), "Train the Trainer - An Experiential way to Effective Teaching", Journal of Engineering Education Transformations; Volume 30, Issue 3, pp. 278283.

[19]Geetha Kiran A, Mohana Lakshmi J., Nanditha B. R. and Chandrashekar H. S. (2017), "An Empirical Vision for Inspiring Students as a Core Driver to meet Global Challenges", Journal of Engineering Education Transformations; Volume 30 , Issue 3 , pp. 65-70. 